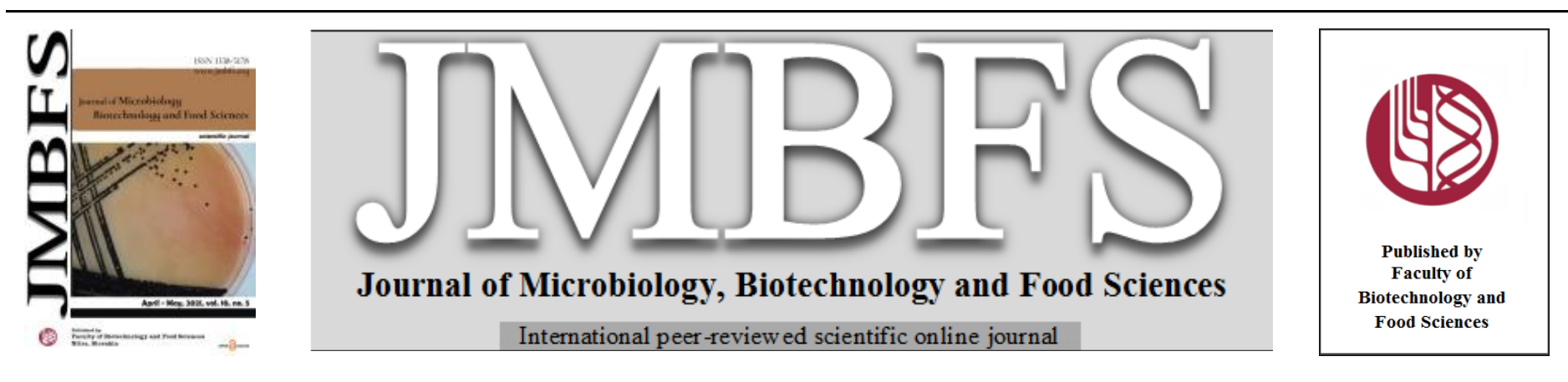

\title{
DESULFURIZATION OF BENZOTHIOPHENE BY AN ISOLATED GORDONIA SP. IITR100
}

\author{
Abrar Ahmad ${ }^{1}$,Varish Ahmad ${ }^{2}$, Mohammad Imran Khan ${ }^{1}$, Othman A.S. Baothman ${ }^{1}$, Mohd. Jahir Khan ${ }^{3}$ \\ Address(es): Dr. Varish Ahmad, \\ ${ }^{1}$ Department of Biochemistry, King Abdulaziz University, Faculty of Sciences, Jeddah, Kingdom of Saudi Arabia. \\ ${ }^{2}$ Health Information Technology Department, Faculty of Applied Studies, King Abdulaziz University, Jeddah, Kingdom of Saudi Arabia. \\ ${ }^{3}$ School of Biotechnology, Jawaharlal Nehru University, New Delhi, India.
}

*Corresponding author: ahmad.varish@gmail.com

https://doi.org/10.15414/jmbfs.2787

\section{ARTICLE INFO}

Received 18. 3. 2020

Revised 28. 11. 2020

Accepted 4. 12. 2020

Published 1. 4. 2021

Regular article

open $O$ access

\begin{abstract}
Different recalcitrant aliphatic and aromatic sulfur compounds e.g. Dibenzothiophene, Benzothiophene, and Di-methyl Dibenzothiophene etc. have been remaining in the petrol and diesel, even after hydrodesulfurization, a chemical method of sulfur impurities removal. These sulfur impurities are required to be removed before it is being transported as fuel. So many microbes have been reported in the last decade showing potential for removing the sulfur impurities by using various pathways at ambient temperature, especially $4 \mathrm{~S}$ pathways. In this study, we describe desulfurization of a model compound Benzothiophene by a Gordonia sp. IITR100 using microbial cell culture and analytical techniques e.g. spectrophotometry and gas chromatography-mass spectrophotometry using column-5. Gordonia sp. IITR100 can grow on Benzothiophene as well as Dibenzothiophene us shown by spectrophotometrical analysis as evident by increased turbidity in aqueous culture. Benzothiophene was metabolized to o-hydroxystyrene as the final product analogous to ' $4 \mathrm{~S}$ ' pathway as Gas Chromatography-Mass Spectra analysis revealed. Gordonia sp. IITR100 have already been shown desulfurization with heavy organosulfur compounds like Thianthrene, and Benzonahpthothiophene to o-hydroxyphenyl phenylsulfone and 2-phenyl-naphthalene-1-ol respectively. The Gordonia sp. IITR100 have shown potential for Desulfurization of heavy and calcitarant sulfur-compounds suggests its potential (broad substrates range) for use in various tough organosulfur fractions in petroleum. Thus, this bacterial strain could be utilized for commercial purpose of biodesulfurization.
\end{abstract}

Keywords: Biodesulfurization, Benzothiophene, Gordonia sp. IITR100, Broad Substrate range

\section{INTRODUCTION}

Organosulfur compounds, Dibenzothiophene (DBT), Di-methyl dibenzothiophene (DMDBT), Benzothiophene (BT), Thianthrene (TN), Dibenzyl sulfide (DBS), Di-thiane (DT), 3-methyl Benzothiophene (3MBT) etc. found in crude oil, petrol, diesel and oils pose numerous serious problems upon burning which brings health problems, acid rain, increased viscosity of a large fraction of crude oil, poisoning of hydro-treatment catalysts and souring of refinery equipment (Denome et al.,1994). Desulfurization of model thiophenic compounds i.e. Dibenzothiophenes (DBT), and their alkylated derivatives, by various isolated organisms has been studied widely, and details of their desulfurization pathways, responsible genes and enzymes have been reviewed extensively (Piddington et al.,1995; Van Hamme et al., 2004; Wanget et al., 2013). Desulfurization of DBT is mediated by a ' $4 \mathrm{~S}$ ' pathway that includes cascade of DszC, DszA and DszB reactions on organosulfur compounds and leading to the formation of hydroxy-biphenyl and related hydroxy products (Van Hamme et al., 2004). NADH-FMN oxidoreductase DszD that allows regeneration of $\mathrm{FMNH}_{2}$ co-factor is also needed for the reactions catalyzed by DszC and DszA. Genes of $4 \mathrm{~S}$ pathway and whole operons dszABC have been characterized from several organisms, reported with well-coordinated activity (Denome et al., 1994; Piddington et al., 1995). In previous studies, different microbes have been reported which grow on DBT, but not on BT e.g. Rhodococcus erythropolis IGTS8. Gordonia sp. 213 E and Rhodococcus sp. Strain WU-K2R grow on BT, but not DBT (Kilbane, 2006; Gilbert et al., 1998; Kirimura et al., 2000). Rhodococcus erythropolis KA2-5-1 and Paenibacillus sp. strain A11-2 are reported to grow on both DBT and BT (Kobayashi et al., 2000; Konishi, 2000). Genetic analysis of degrading BT has also been reported with Gordonia terrae Strain C-6 (Brooks et al., 2012). Gordonia sp. IITR100 has been reported to grow on Dibenzyl sulfide, Thianthrene and Benzonaphthothiophene (BNTH) along with DBT (Ahmad et al., 2014; Ahmad et al., 2015; Chauhan et al., 2015). Gordonia sp. IITR100 has described with a significant potential to reduce the sulfur content from diesel upto $76 \%$. (Adlakha et al., 2016). Whole genome sequence (Jaishankar et al., 2017) and feed-back inhibition of 2-HBP (end product of $4 \mathrm{~S}$ pathway) have been studied to happened by TetR family proteins (Murarka et al., 2018; Murarka et al., 2018; Murarka et al., 2019). Here we reported that Gordonia sp. IITR 100 could grow on BT along with DBT, producing o-hydroxystyrene and 2-HBP as the final metabolic end products analogous to $4 \mathrm{~S}$ pathways. Thus, Gordonia sp. IITR100 has potential for industrial application of Biodesulfurization.

\section{MATERIALS AND METHODS}

\section{Chemicals}

DBT, BT, BNTH. TN and acetonitrile were purchased from Sigma-Aldrich (St Louis, MO, USA) and Ethyl acetate from MERCK-Schuchardt (Mumbai, India). All the other chemicals used were of analytical grade.

\section{Isolation and characterization of Bacterium}

A bacterium Gordonia sp. IITR100 (GU084407), isolated from an oilcontaminated soil around a refinery in Gujarat, India and its isolation, characterized and potentiality for petroleum industry were discussed in our previously conducted research (Singh et al., 2011). In this research, we have explored the potentiality of this bacterial isolate for the desulfurization of DBT and DMDBT

\section{Assay Desulfurization by Gordonia sp. IITR100}

IITR100 cells, grown on DBT, were used as inoculums for all the experiments. For BT and DBT desulfurization, 20 flasks (100 ml capacity) containing $20 \mathrm{ml}$ medium-1 $\left(\mathrm{Na}_{2} \mathrm{HPO}_{4}, 2.0 \mathrm{~g} ; \mathrm{KH}_{2} \mathrm{PO}_{4}, 1 \mathrm{~g} ; \mathrm{MgCl}_{2} \cdot 6 \mathrm{H}_{2} \mathrm{O}, 0.4 \mathrm{~g} ;\left(\mathrm{NH}_{4}\right)_{2} \mathrm{C}_{2} \mathrm{O}_{4}, 4.25\right.$ $\mathrm{g} ; \mathrm{Al}(\mathrm{OH})_{3}, 0.1 \mathrm{~g} ; \mathrm{SnCl}_{2} .2 \mathrm{H}_{2} \mathrm{O}, 0.5 \mathrm{~g} ; \mathrm{KI}, 0.05 \mathrm{~g} ; \mathrm{LiCl}, 0.01 \mathrm{~g} ; \mathrm{MnCl}_{2} .4 \mathrm{H}_{2} \mathrm{O}, 0.8$ $\mathrm{g} ; \mathrm{H}_{3} \mathrm{BO}_{3}, 0.05 \mathrm{~g} ; \mathrm{ZnCl}_{2}, 0.1 \mathrm{~g} ; \mathrm{CoCl}_{2} \cdot 6 \mathrm{H}_{2} \mathrm{O}, 0.1 \mathrm{~g} ; \mathrm{NiCl}_{2} \cdot 6 \mathrm{H}_{2} \mathrm{O}, 0.1 \mathrm{~g} ; \mathrm{BaCl}_{2}$ $0.05 \mathrm{~g}$; $\left(\mathrm{NH}_{4}\right)_{6} \mathrm{Mo}_{7} \mathrm{O}_{24} .4 \mathrm{H}_{2} \mathrm{O}, 0.05 \mathrm{~g}, 17.1 \mathrm{~g}$ Sucrose, per liter, supplemented with $50 \mathrm{mg}$ of either BT or DBT per liter as experimental design required sulfur 
source in each separate flask, were inoculated with IITR100 at $30{ }^{\circ} \mathrm{C}, \mathrm{pH} 7$ in triplicate for a time period $0,2,4,6$, and 8 days. The samples from each set of experimental flask were removed for estimation of growth by spectrophotometer (absorbance at $600 \mathrm{~nm}$ ). The reaction was stopped by acidification to $\mathrm{pH}<2.0$ using $2 \mathrm{~N} \mathrm{HCl}$, and levels of residual BT and formed metabolites were analyzed analytically using High performance Liquid Chromatography (HPLC) and Gas Chromatography-Mass Spectrometry (GC-MS). BT (From Sigma) was used as standard reference (Ahmad et al., 2014; Ahmad et al., 2015; Chauhan et al. 2015). Moreover, to explore the Desulfurization potentialities of this strain, a set of experiments were also conducted at similar incubation conditions $\left(30{ }^{\circ} \mathrm{C} ; \mathrm{pH}\right.$ 7) to test the desulfurization of BNTH (Organic sulfur source) and Sodium Sulphate (inorganic sulfur source). A negative control without any sulfur source was also used. Stoppered flasks were used for setting the experiment with BT in order to prevent the sublimation of BT. All the sets of experiment were conducted in triplicates and statistically mean values were used to interpret the results. Standards analysts as a control from Sigma were used for data validation in HPLC and GC (Ahmad et al., 2014; Ahmad et al., 2015; Chauhan et al., 2015).

\section{Analysis of BT by HPLC and GC}

After acidification of culture medium, the $20 \mathrm{ml}$ reaction mixture was extracted three times with equal volume of ethyl acetate at room temperature and evaporated. The residue obtained after complete evaporation of the solvent was dissolved in $200 \mu \mathrm{l}$ acetonitrile and $1 \mu \mathrm{l}$ diluted aliquot was used for HPLC analysis using Waters instrument (Milford, MA, USA), equipped with a PDA 996 detector and LiChrospher ${ }^{\circledR} 100 \mathrm{RP}-18$ columns $(5 \mu \mathrm{m}, 4.6 \times 250 \mathrm{~mm})$. It was run at $25{ }^{\circ} \mathrm{C}$, using $100 \%$ acetonitrile as mobile phase at the flow rate $0.50 \mathrm{ml} / \mathrm{min}$. There should not be any time lapse in stoping the reaction with $2 \mathrm{~N} \mathrm{HCl}$ and extraction and its running on HPLC and GC analysis of BT and its metabolites. Care has to be taken while handling the BT in comparison to DBT (Ahmad $\boldsymbol{e}$ t al., 2014; Ahmad et al., 2015; Chauhan et al., 2015).

For Gas chromatography and mass-spectroscopy, analysis of samples was performed using Trace GC Ultra (Thermo Scientific, USA), equipped with Triplus Auto Sampler coupled with TSQ Quantum XLS Mass spectrometer and TG-5MS capillary column $(30 \mathrm{~m} \times 0.25 \mathrm{~mm} \mathrm{ID} \times 0.25 \mu \mathrm{m}$ film thickness $)$. To run the instrument, the oven temperature was maintained at $100{ }^{\circ} \mathrm{C}$ for $2.0 \mathrm{~min}$, followed with escalation to $150{ }^{\circ} \mathrm{C}$ at the rate of $15^{\circ} \mathrm{C} / \mathrm{min}$ for $0 \mathrm{~min}$, to $200{ }^{\circ} \mathrm{C}$ at the rate of $3{ }^{\circ} \mathrm{C} / \mathrm{min}$ for $0 \mathrm{~min}$ and to $260^{\circ} \mathrm{C}$ at the rate of $30^{\circ} \mathrm{C} / \mathrm{min}$, where it was held for $6.0 \mathrm{~min}$. Injector temperature; $250{ }^{\circ} \mathrm{C}$, CT split value; 20, mass range; 50-600 amu, source Temp; $220^{\circ} \mathrm{C}$, and transfer line temp; $290{ }^{\circ} \mathrm{C}$. Helium was used as carrier gas at a flow rate of $1.0 \mathrm{ml} / \mathrm{min}$ (Ahmad et al., 2014; Ahmad et al., 2015; Chauhan et al., 2015).

\section{RESULTS AND DISCUSSION}

\section{Desulfurization of BT by IITR100}

The desulfurization potentialities of Gordonia sp. IITR100 for DBS, BNTH and TN have been explored in our previously conducted researches (Ahmad $\boldsymbol{e t}$ al., 2014; Ahmad et al., 2015; Chauhan et al., 2015). In this study strain IITR100 has also found to be growing in liquid medium supplemented with BT, DBT, BNTH or Sodium Sulfate $\left(\mathrm{NaSO}_{4}\right)$ as sole source of sulfur.

We have observed no growth of the isolated strain IITR100 in experimental flask incubated without any sulfur source (Figure 1).

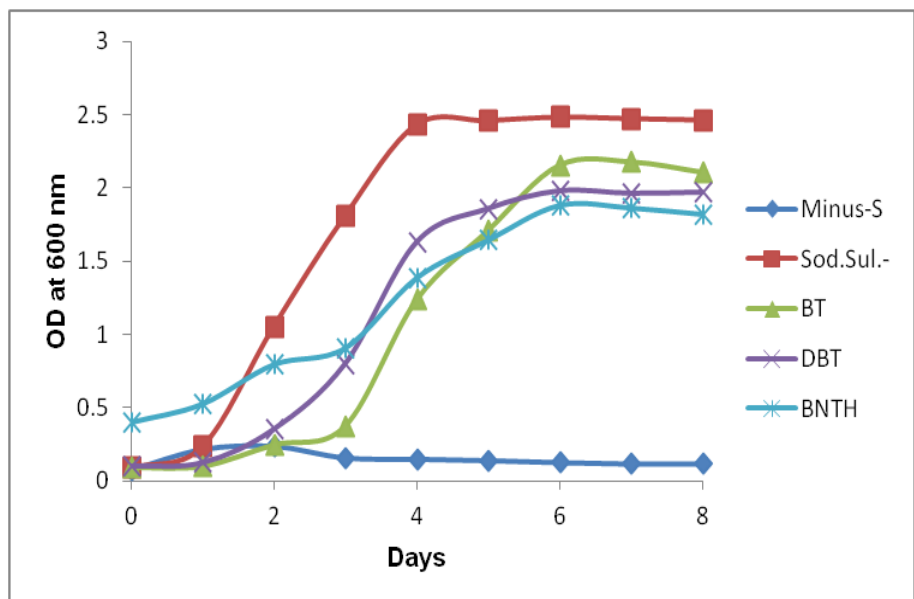

Figure 1 Growth of Gordonia sp. IITR 100 on different organosulfur compounds

However, significant growth was found to be with experimental flask supplemented with BT, DBT, BNTH and Sodium sulfate. Moreover, the bacterial growth accompanied with the formation of Gibbs positive products with BT, DBT, and BNTH, but there was no any Gibbs positive product formation found to be in the medium supplemented with Sodium sulfate used as a sulfur sources (Figure 2).

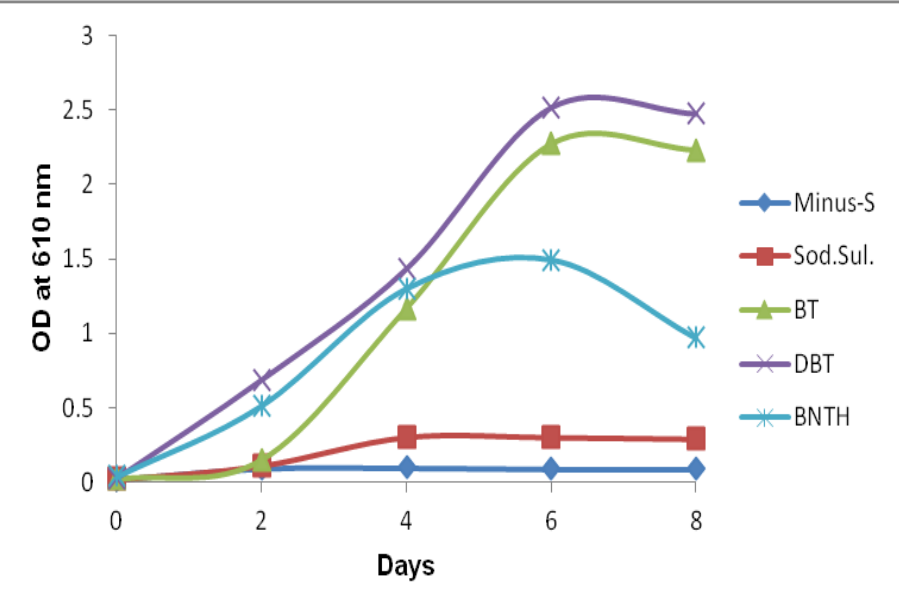

Figure 2 Gibb's assay of Gordonia sp. IITR 100 on different organosulfur compounds

With time passes with incubation, Gibbs positive metabolites was observed to be increased up to 6 days and became stationary after that. Gibbs positive material formation reflects hydroxlated product generation which is the end product of $4 \mathrm{~S}$ pathway. $4 \mathrm{~S}$ pathway is sulfur specific metabolic pathway which conserves the fuel value of organosulfur compounds.

\section{Degradation of BT and DBT}

Degradation of both BT and DBT with IITR100 was studied and results are observed as shown in Figure 3 and Figure 4.

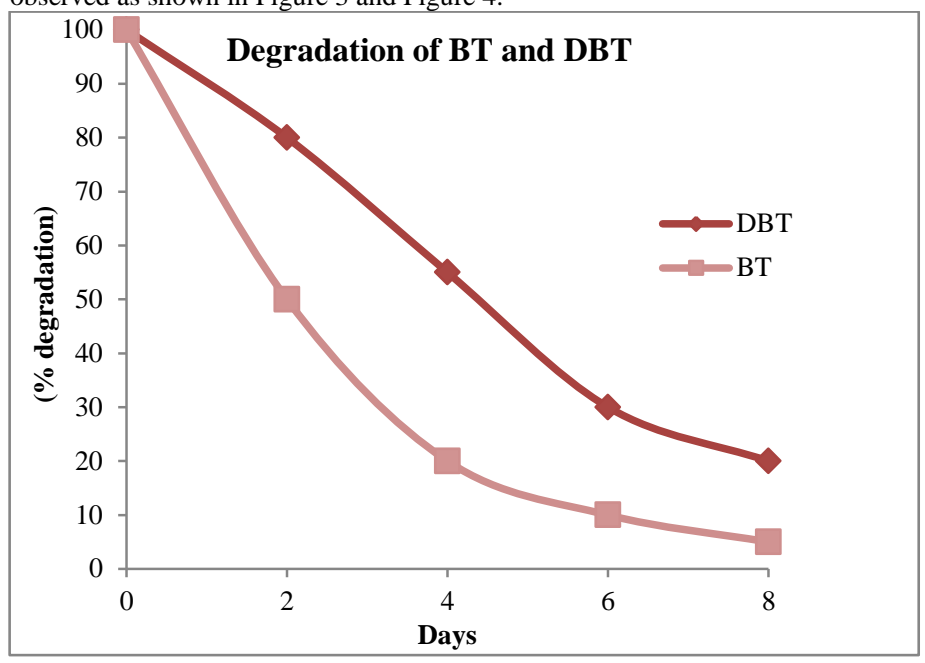

Figure 3 Desulfurization/metabolism of BT (Rectangle filled) and DBT (Rectangle unfilled) with IITR100, when present separately.

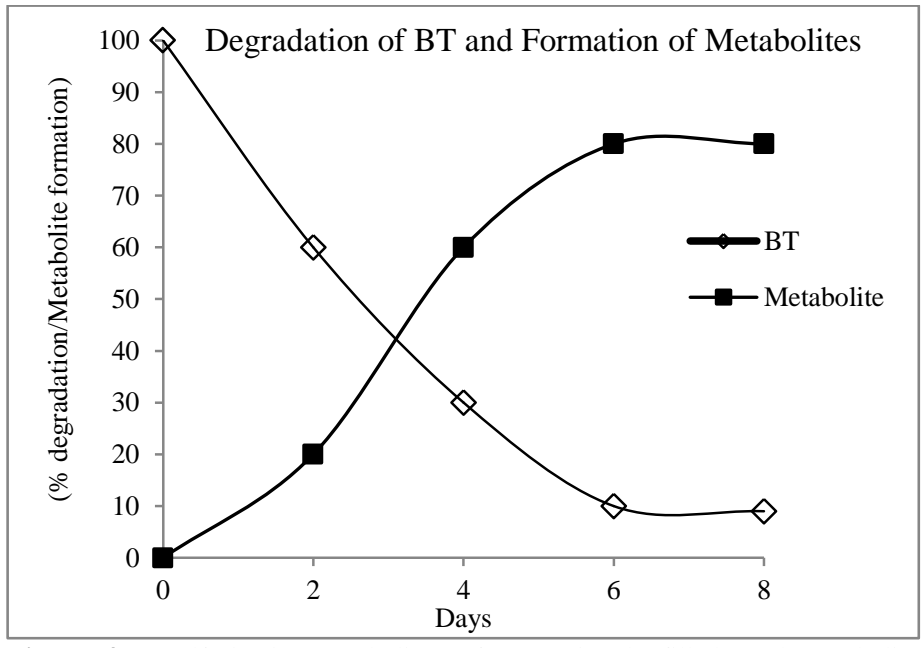

Figure 4 Desulfurization/metabolism of BT (triangle filled) and metabolite formation (open triangle) with IITR100 
BT and DBT, both were degraded up to $95 \%$ and $80 \%$ up to 8 days (Figure 3 ). Degradation of BT was followed by the formation of o-hydroxystyrene (Figure 4). As the concentration of BT decreases the concentration of its metabolite (ohydroxystyrene) increases. DBT was degraded with the formation of 2-HBP Based on the analogy with the 2-HBP formation from DBT and o-hydroxystyrene formation from BT, the possible pathway of BT metabolism is proposed from BT to Benzothiophene sulfoxide to Benzothiophene sulfone to Benzothiophene sulfinate to o-hydroxystyrene (Figure 5). The statistical analysis was performed and analyzed $\mathrm{P}$ value $(\mathrm{p} \leq 0.05)$.) was found to be significant
(A)<smiles>c1ccc2c(c1)CCS2</smiles>

Benzothiophene

D

(B)<smiles>C=S1c2ccccc2-c2ccccc21</smiles>

Benzothiophene sulfoxide

(C)<smiles>O=S1(=O)c2ccccc2-c2ccccc21</smiles>

(D)<smiles>O=S1C=Cc2ccccc2O1</smiles>
$\longrightarrow$

(F)

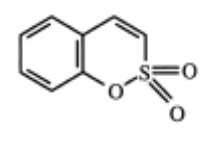

Benzothiophene sulfinate

(E)<smiles>C=Cc1ccccc1O</smiles>

O-Hydroxy-styerene
Figure 5 Possible pathway of BT desulfurization based on final metabolite,ohydroxystyrene by Gordonia sp. IITR 100

\section{CONCLUSION}

Previously Desulfurization of BT has been shown by some of few bacteria, but they do not grow on DBT e.g. Gordonia sp. 213 E. Some have shown the desulfurization of DBT, but not BT e.g. Rhodococcus sp. IGTS8. Few bacteria have been reported to grow on Both DBT and BT e.g. Rhodococcus erythropolis KA2-5-1 and Paenibacillus sp. strain A11-2. Differential behavior of bacterium for DBT and BT tells about kinds of adaption in microbes. Gordonia alkanivorans strain 1B preferentially desulfurizes BT than DBT (Alves $\boldsymbol{e t}$ al. 2005). In this research, with the best of our knowledge this study is the first to report the Gordonia sp. IITR100 can desulfurize the Benzothiophene to ohydroxystyrene analogous to 2-HBP generation from DBT. Gordonia terrae Strain C-6 also desulfurize the BT to the o-hydroxystyrene which support the results of this study. Gene systems involved in desulfurization BT have been revealed by Wei Wang et at (Wang et al., 2013). They demonstrated that the genes and operons involved for BT desulfurization is the same as $d s z A, d s z B$ and $d s z C$ and operons system $d s z A B C$. In earlier reports, Gordonia sp. IITR100 have been reported to desulfurize the dibenzyle sulfide to benzoic acid (Ahmad $\boldsymbol{e t}$ al. 2015), Thianthrene to o-hydroxyphenyl phenylsulfone (Ahmad et al., 2014), Banzonaphthothiophene to 2-phenyl-naphthalene-1-ol (Chauhan et al., 2015) Gordonia sp. IITR 100 reduces $76 \%$ and $56 \%$ sulfur from diesel oil and crude oi (Adlakha et al., 2016). This strain Gordonia sp. IITR100 has broader substrate range and good desulfurization potential, hence it can be used for industria application of biodesulfurization. Whole genome sequence has been reveled for this strain IITR 100 (Jaishankar et al., 2018), so pathway engineering can be done to further reduce the 2-HBP feedback inhibition and improve the activity (Wang et al., 2017). Efforts are on the way to find out the protein family and DNA regions involved in reducing/inhibiting desulfurizing activity of $4 \mathrm{~S}$ pathways. Several such proteins and their family have been reported to belong to TetR group proteins (Murarka et al., 2018; Murarka et al., 2019). Actinomycete organisms belonging to the genus Rhodococcus and related taxa have been also described to desulfurize the BT and Dibenzothiophene (Oldfield et al., 1998). Gordonia strain CYKS1 and Nocardia sp. strain CYKS2 desulfurize diesel and Dibenzothiophene but not reported for desulfurization of BT (Rhe et al., 1998; Chang et al., 1998). Thus, we can conclude that Gordonia $s p$. IITR 100 has broad substrate range for various organosulfur compounds from diesel and crude oil and it can be used for commercial purpose of biodesulfurization. It has great potential for ambient desulfurization. So it can be further optimized parallel to the hydrodesulfurization (HDS).

Acknowledgements: Deanship of Scientific Research (DSR), King Abdulaziz University Jeddah, KSA, under Grant No. (DF-793-156-1441) is gratefully acknowledged for technical and financial support.

\section{REFERENCES}

Adlakha, J., Singh, P., Saurabh, R. K., Kumar, M., Singh, M.P., Singh, D. Sahai, V., \& Srivastava, P., (2016). Optimization of conditions for deep Desulfurization of heavy crude oil and hydrodesulfurized diesel by Gordonia sp. IITR100. Fuel, 184, 761-769. https://doi.org/10.1016/j.fuel.2016.07.021

Ahmad, A., Chauhan, A.K., Javed, S., \& Kumar, A., (2014). Desulfurization of Thianthrene by Gordonia sp. IITR100. Biotechnol Let, 36, 2209-2214. https://doi.org/10.1007/s10529-014-1606-2

Ahmad, A., Chauhan, A.K., Kushwaha, H.N., Javed, S., \& Kumar, A.,(2015).

Preferential Desulfurization of Dibenzylsulfide by an isolated Gordonia sp. IITR100. 3 Biotech, 5, 237-243.

Alves, L., Salgueiro R., Rodrigues, C., Mesquita, E., Matos, J., Gírio, F.M (2005). Desulfurization of dibenzothiophene, benzothiophene, and other thiophene analogs by a newly isolated bacterium, Gordonia alkanivorans strain 1B. Appl Biochem and Biotechnol, 120(3), 199-208. https://doi.org/10.1385/abab:120:3:199

Brooks, S.L.,\&Van Hamme, J.D., (2012). Whole-Genome Shotgun Sequence of Rhodococcus Species Strain JVH1. J Bacteriol, 194(19), 5492-5493. https://doi.org/10.1128/jb.01066-12

Chang, J.H., Rhee, S.K., Chang, Y.K., \& Chang, H.N.,(1998). Desulfurization of diesel oils by a newly isolated dibenzothiophene-degrading Nocardia sp. strain CYKS2. Biotechnol Prog, 14, 851-855. https://doi.org/10.1021/bp9800788

Chauhan, A.K., Ahmad, A., Singh, S.P., \& Kumar, A., (2015). Biodesulfurization of Benzonaphthothiophene by a newly isolated Gordoniasp. IITR100. Int. $\begin{array}{llll}\text { Biodeterio and } \quad \text { Biodegrad, 104, } & \text { 111. }\end{array}$ https://doi.org/10.1016/j.ibiod.2015.05.024.

Denome, S.A., Oldfield, C., Nash, L.J., \&Young, K.D., (1994). Characterization of the Desulfurization genes from Rhodococcus sp. strain IGTS8. J Bacteriol, 176-6707-16. https://doi.org/10.1128/jb.176.21.6707-6716.1994

Denome, S.A., Oldfield, C., Nash, L.J., \& Young, K.D., (1994). Characterization of the Desulfurization genes from Rhodococcus sp. strain IGTS8. J Bacteriol, 176, 6707-6716. https://doi.org/10.1128/jb.176.21.6707-6716.1994

Gilbert, S.C., Morton, J., Buchanan, S., Oldfield, C.\& McRoberts, A.,(1998). Isolation of a unique Benzothiophene desulfurizing bacterium, Gordona sp. strain 213E (NCIMB 40816), and characterization of the Desulfurization pathway. Microbiol, 144, 2545-2553.

Jaishankar, J., Singh, P., \& Srivastava, P. (2017). Draft Genome Sequence of a Biodesulfurizing Bacterium, Gordonia sp. Strain IITR100. Genome announcements, 5(17), e00230-17. https://doi.org/10.1128/genomeA.00230-17.

Kilbane J. J., 2nd (2006). Microbial biocatalyst developments to upgrade fossil fuels. Current opinion in biotechnology, 17(3), 305-314. https://doi.org/10.1016/j.copbio.2006.04.005

Kirimura, K., Furuya, T., Sato, R., Ishii, Y., Kino, K., \& Usami, S. (2002). Biodesulfurization of naphthothiophene and benzothiophene through selective cleavage of carbon-sulfur bonds by Rhodococcus sp. strain WU-K2R. Applied $\begin{array}{lll}\text { and environmental microbiology, 68(8), 3867-3872. } & \text { 387 }\end{array}$ https://doi.org/10.1128/aem.68.8.3867-3872.2002.

Kirkwood, K. M., Ebert, S., Foght, J. M., Fedorak, P. M., \& Gray, M. R. (2005) Bacterial biodegradation of aliphatic sulfides under aerobic carbon- or sulfurlimited growth conditions. Journal of applied microbiology, 99(6), 1444-1454 https://doi.org/10.1111/j.1365-2672.2005.02723.x.

Kobayashi, M., Onaka, T., Ishii, Y., Konishi, J., Takaki, M., Okada, H., Ohta, Y. Koizumi, K., \& Suzuki, M. (2000). Desulfurization of alkylated forms of both dibenzothiophene and benzothiophene by a single bacterial strain. FEMS microbiology letters, 187(2), 123-126. https://doi.org/10.1111/j.15746968.2000.tb09147.x

Konishi, J., Onaka, T., Ishii, Y., \& Suzuki, M. (2000). Demonstration of the carbon-sulfur bond targeted desulfurization of benzothiophene by thermophilic Paenibacillus sp. strain A11-2 capable of desulfurizing dibenzothiophene. FEMS microbiology letters, 187(2), 151-154. https://doi.org/10.1111/j.15746968.2000.tb09152.x

Murarka P, Srivastava P. Characterization of DNA binding and ligand binding properties of the TetR family protein involved in regulation of dsz operon in Gordonia sp. IITR100. Int J Biol Macromol. 2019 Dec 1;141:671-679. https://doi.org/10.1016/j.ijbiomac.2019.09.009.

Murarka, P., \& Srivastava, P., (2018). An improved method for the isolation and identification of unknown proteins that bind to known DNA sequences by affinity capture and mass spectrometry. PLoSOne, 23,13(8) https://doi.org/10.1371/journal.pone.0202602

Oldfield, C., Wood, N. T., Gilbert, S. C., Murray, F. D., \& Faure, F. R. (1998) Desulphurisation of benzothiophene and dibenzothiophene by actinomycete 
organisms belonging to the genus Rhodococcus, and related taxa. Antonie van Leeuwenhoek, 74(1-3), 119-132. https://doi.org/10.1023/a:1001724516342.

Piddington, C. S., Kovacevich, B. R., \& Rambosek, J. (1995). Sequence and molecular characterization of a DNA region encoding the dibenzothiophene desulfurization operon of Rhodococcus sp. strain IGTS8. Applied and environmental microbiology, 61(2)

$468-475$.

https://doi.org/10.1128/AEM.61.2.468-475.1995.

Rhee, S. K., Chang, J. H., Chang, Y. K., \& Chang, H. N. (1998). Desulfurization of dibenzothiophene and diesel oils by a newly isolated gordona strain, CYKS1. Applied and environmental microbiology,64(6), 2327-2331. https://doi.org/10.1128/AEM.64.6.2327-2331.1998.

Singh, P., Ahmad, A., Faraz, S., Macwan, A., Kumar, A., Srivastava, P., (2011) Desulfurization of recalcitrant organosulfur compound 4, 6-DMDBT by the isolated strain IITR100. Proceedings of the $80^{\text {th }}$ meeting of 'Society of Biological chemists (India).

Van Hamme, J.D., Fedorak, P.M., Foght, J.M., Gray, M.R., Dettman, H.D. (2004). Use of a novel fluorinated organosulfur compound to isolate bacteria capable of carbon-sulfur bond cleavage. Appl Environ Microbiol, 70(3),14871493. https://doi.org/10.1128/aem.70.3.1487-1493.2004

Van Hamme, J.D., Wong, E.T., Dettman, H., Gray, M.R., Pickard, M.A., (2003). Dibenzyl sulfide metabolism by white rot fungi. Appl Environ Microbiol, 69 1320-1324. https://doi.org/10.1128/aem.69.2.1320-1324.2003

Wang, J., Butler, R.R., Wu F, Pombert, J.F., Kilbane, J.J, Stark, B.C., (2017) Enhancement of Microbial Biodesulfurization via Genetic Engineering and $\begin{array}{lllll}\text { Adaptive } \quad \text { Evolution. } & \text { One }, & \text { 6 } & \text { 12(1) }\end{array}$ https://doi.org/10.1371/journal.pone.0168833

Wang, W., Ma, T., Lian, K., Zhang, Y., Tian, H., Ji, K., Li, G., (2013). Genetic Analysis of Benzothiophene Biodesulfurization Pathway of Gordonia terrae Strain C-6. PlosOne, 8(12), 84386. https://doi.org/10.1371/journal.pone.0084386 